\title{
APRESENTAÇÃO
}

\section{Os manuscritos medievais da Universidade de Brasília}

\section{Organizadora}

Prof ${ }^{a}$. Dra . Alícia Duhá Lose

Professora da Universidade Federal da Bahia, Brasil Doutora em Letras e Linguística pela Universidade Federal da Bahia, Brasil Pós-Doutora em História pela Universidade de Coimbra, Portugal e-mail: alicia.lose@ufba.br

ORCID: https://orcid.org/0000-0002-9114-3298 DOI: http://dx.doi.org/10.26512/hh.v7i14.26254

Era uma vez três belos códices, certamente produzidos em algum mosteiro português entre os séculos XIV ou XV, que muitos anos depois, por volta de 1925, foram adquiridos na Vila do Conde, em Portugal, pelo Dr. Jorge de Faria. Nessa época, já não eram mais "códices". Eram folhas de pergaminho soltas, pouco mais de 200, oriundas certamente de algum mosteiro ou casa religiosa de que saíram, ou por causa da extinção das ordens em 1834, ou por causa de atos violentos que se seguiram relacionados aos movimentos que levaram à proclamação da República em Portugal, em 05 de outubro de 1910.

Por volta de 1925 estavam emprestados à Biblioteca Nacional de Lisboa, onde foram lidos e copiados por Pedro de Azevedo.

Quem nos conta essa história é Serafim da Silva Neto (1956), ilustre filólogo brasileiro, no seu livro Textos medievais e seus problemas.

Alguns anos mais tarde, o também filólogo e linguista Nelson Rossi nos informa que esses textos foram adquiridos pelo erudito professor Silva Neto que os teria trazido para o Brasil em 1950.

Em 1964 foram vendidos pela viúva do professor Serafim, a Sra. Cremilda de Carvalho e Silva, à Universidade de Brasília (UnB).

Nesse mesmo ano, um dos documentos foi levado para restauração na Biblioteca Nacional, do Rio de Janeiro, e os outros dois seguiram para Universidade Federal da Bahia aos cuidados do Prof. Nelson Rossi.

Em 1972 os manuscritos são levados novamente à Universidade de Brasília em razão da inauguração do atual prédio da sua Biblioteca Central (BCE), onde permanecem até hoje sob os devidos cuidados que recomendam sua importância.

Infelizmente, entre os "mais de 200 fólios" mencionados por Silva Neto e os que a Universidade de Brasília dispõem hoje, faltam algumas dezenas. O recibo de compra dos 
documentos não especifica a quantidade de fólios adquirida, mas atualmente, restam apenas 168 fólios e meio.

Os manuscritos aos quais nos referimos são escritos em português arcaico e configuram um tesouro histórico e linguístico incomparável posto representarem, em terras brasileiras, os primeiros monumentos da Língua Portuguesa e trazerem toda a carga da cristandade lusitana que tanto influenciou a formação da nossa sociedade.

Durante essa estada no Nordeste, esses mesmos manuscritos influenciaram, diretamente, na composição de dois núcleos de pesquisa consolidados na Universidade Federal da Bahia, nas áreas de Filologia e Linguística histórica, gerando diversos estudos sobre eles e a edição de dois dos documentos. Na Universidade de Brasília também são importantes fontes históricas exploradas pelos diversos cursos que ela mantém, mas principalmente atendendo ao Programa de Estudos Medievais do Departamento de História.

A origem exata de sua produção é ainda desconhecida, mas a tese que prevalece, baseada em referências de catálogos da biblioteca medieval do Oratório de São Clemente das Penhas, em Leça da Palmeira, Portugal, é de que sejam oriundos de algum mosteiro ao norte de Portugal, nas proximidades de Braga.

Os documentos/monumentos medievais - os famosos "manuscritos medievais da UnB" - são o fragmento de oito fólios e meio do Livro das Aves, 79 fólios dos Diálogos de São Gregório e 81 fólios do Flos Sanctorum. Pensando em difundir e dar a conhecer a um público mais amplo os manuscritos medievais da $\mathrm{UnB}$, os documentos se encontram agora acessíveis através do site da Biblioteca Central da universidade, no endereço http://bdce.unb.br.

Assim, o leitor deste número especial terá acesso aos textos que abordam desde os aspectos mais exteriores dos documentos até análises mais aprofundadas das características internas dos três manuscritos.

Saul António Gomes, investigador da Faculdade de Letras da Universidade de Coimbra, parte do universo da codicologia na qual se insere o livro religioso medieval em território português para tecer considerações relativas aos três manuscritos medievais pertencentes a Universidade de Brasília. Segundo o historiador português, "os manuscritos medievais da UnB não intermedeiam um texto originariamente em latim, mas antes um texto traduzido em língua portuguesa para melhor compreensão dos leitores a que se destinavam".

Américo Venâncio Lopes Machado Filho, pesquisador do Instituto de Letras da Universidade Federal da Bahia, afirmando serem os manuscritos medievais da UnB os documentos mais antigos escritos em língua portuguesa existentes no Brasil, discute aspectos 
linguísticos como comprobatórios do valor maior desses manuscritos, qual seja, a possibilidade de representarem a variação e os processos de mudança culturais ao longo da história refletidos nos aspectos da memória linguístico-literária, ainda livre das amarras normativas.

Cláudia Costa Brochado, também do Programa de Estudos Medievais da Universidade de Brasília, apresenta uma possibilidade de análise dos manuscritos medievais da UnB em sala de aula como fonte documental para compreender melhor a Idade Média e faz isso através do exemplo bem-sucedido de análise das personagens femininas, como Benedita e Pelágia do Flos Sanctorum.

Maria Aparecida Torres Morais, da Faculdade de Filosofia, Letras e Ciências Humanas da Universidade de São Paulo, investiga a ocorrência de possessivos na língua portuguesa do séc. XIV e no português brasileiro contemporâneo considerando a distribuição do pronome seu pré-nominal na relação com outras estratégias de expressão da posse a partir do estudo do texto presente nos fólios do Flos Sanctorum. As conclusões da pesquisadora corroboram com as características inovadoras do português do Brasil.

Heloisa Salles, Rozana Naves e Eloisa Pilati, pesquisadoras do Instituto de Letras da Universidade de Brasília, trazem mais uma possibilidade de análise linguística dos documentos. Contextualizando a socio-história do português brasileiro, a partir dos Diálogos de São Gregório, a investigação das orações reduzidas de infinitivo no português arcaico que apresentam, demostra que, "a despeito das propriedades inovadoras em relação ao sistema pronominal e flexional, o infinitivo flexionado se mantém produtivo nessa língua".

Todos estes temas e debates acerca dos três manuscritos medievais da Universidade de Brasília nos levam a fazer, a exemplo de Machado Filho em seu artigo aqui apresentado, uma justa homenagem "às memórias de Rosa Virgínia Mattos e Silva e Nelson Rossi e a todos os que contribuem para a preservação e divulgação de espólios documentais e, em especial, dos Manuscritos Serafim da Silva Neto".

\section{REFERÊNCIAS BIBLIOGRÁFICAS:}

ROSSI, Nelson et al. Livro das Aves. Edição crítica, introdução e glossário. Rio de Janeiro: Instituto Nacional do Livro, 1965.

SILVA NETO, Serafim. Textos medievais e seus problemas. Rio de Janeiro: MEC; Casa Rui Barbosa, 1956. 